\title{
Quality of second season soybean submitted to drying and storage ${ }^{1}$
}

\author{
Cesar Pedro Hartmann Filho², André Luís Duarte Goneli², \\ Tathiana Elisa Masetto ${ }^{2}$, Elton Aparecido Siqueira Martins ${ }^{2}$, Guilherme Cardoso $\mathrm{Oba}^{2}$, Valdiney Cambuy Siqueira ${ }^{2}$
}

\section{ABSTRACT}

Drying agricultural products reduces the moisture content to suitable levels for storage, in order to maintain the product quality. However, special care with the temperatures applied in the process is important for the integrity and longevity of the material. The present study aimed at determining the immediate and latent effect of air-drying temperatures on the quality of soybean produced as a second season crop. The grains were collected at the R8 stage, close to the physiological maturity, with moisture content of approximately $23 \%$ (w.b.), submitted to drying temperatures of $40{ }^{\circ} \mathrm{C}, 50{ }^{\circ} \mathrm{C}, 60{ }^{\circ} \mathrm{C}, 70{ }^{\circ} \mathrm{C}$ and $80{ }^{\circ} \mathrm{C}$, up to a moisture content of $12.5 \pm 0.7 \%$ (w.b.), and then stored under non-controlled humidity and temperature for 180 days. Thereafter, quality was assessed every 45 days by determining the dry matter loss, color and crude protein and lipid contents, as well as the acidity and peroxide indices of the crude oil extracted. Based on the results obtained, it was concluded that the increase in the air-drying temperature affects the soybean quality and crude oil extracted, being this effect enhanced with the storage time; the soybean and crude oil quality decline with an increase in the air-drying temperature and storage time; the air temperature of $40{ }^{\circ} \mathrm{C}$ has the least effect on the quality of soybean grains and crude oil extracted.

KEY-WORDS: Glycine max L.; grain quality; post-harvest.

\section{INTRODUCTION}

Soybean is one of the main aleuro-oleaginous grown worldwide, due to its distinct characteristics, which provide high profitability per unit area and favorable market conditions (Sediyama et al. 2013). These characteristics include its protein-rich composition, which ranges $30-53 \%$, and oil content of 13-28\% (Bezerra et al. 2015).

\section{RESUMO}

Qualidade de soja produzida em segunda safra submetida a secagem e armazenamento

A secagem de produtos agrícolas reduz o teor de água a níveis adequados para o armazenamento, visando à manutenção da qualidade do produto. Porém, cuidados especiais com as temperaturas aplicadas no processo são importantes para a integridade e longevidade do material. Objetivou-se determinar o efeito imediato e latente de temperaturas do ar de secagem sobre a qualidade de soja produzida em segunda safra. Os grãos foram colhidos no estádio $\mathrm{R} 8$, próximo à maturidade fisiológica, com teor de água de, aproximadamente, $23 \%$ (b.u.), e foram submetidos a temperaturas de secagem de $40{ }^{\circ} \mathrm{C}, 50^{\circ} \mathrm{C}, 60^{\circ} \mathrm{C}, 70^{\circ} \mathrm{C}$ e $80{ }^{\circ} \mathrm{C}$, até o teor de água de $12,5 \pm 0,7 \%$ (b.u.), sendo, posteriormente, armazenados em ambiente com condições de temperatura e umidade não controladas, durante 180 dias. A cada 45 dias subsequentes, a qualidade foi avaliada por meio de determinação da perda de matéria seca, coloração e teores de proteína bruta e de lipídios e pelos índices de acidez e de peróxido do óleo bruto extraído. Com base nos resultados obtidos, conclui-se que o aumento da temperatura do ar de secagem influencia na qualidade da soja e do óleo bruto extraído, sendo esse efeito potencializado com o tempo de armazenamento; a qualidade da soja e do óleo bruto se reduzem conforme o incremento na temperatura do ar de secagem e no tempo de armazenamento; a temperatura do ar de $40^{\circ} \mathrm{C}$ é a que menos afeta a qualidade dos grãos de soja e do óleo bruto extraído.

PALAVRAS-CHAVE: Glycine max L.; qualidade de grãos; pós-colheita.

Approximately 33.228.400 million hectares of soybean were planted in the 2015/2016 season, resulting in a total production of 95.574 .4 thousand tons and average yield of $2.876 \mathrm{~kg} \mathrm{ha}^{-1}$ (Conab 2016), making it the most widely grown crop in the country.

Nevertheless, a series of problems for obtaining high quality has always been present in this system, compromising both its market range and commercialization value (Alencar et al. 2009).

1. Manuscript received in May/2016 and accepted for publication in Sep./2016 (http://dx.doi.org/10.1590/1983-40632016v4641380).

2. Universidade Federal da Grande Dourados, Faculdade de Ciências Agrárias, Dourados, MS, Brazil.

E-mails: cphartmann21@hotmail.com, andregoneli@ufgd.edu.br, tathianamasetto@ufgd.edu.br, eltonmartins@ufgd.edu.br, guilherme_oba@hotmail.com,vcambuy@yahoo.com. 
Thus, alternatives aimed at addressing these issues have been increasingly used in recent years, such as increasing soybean planting at atypical times (e.g. as a second crop). In addition, the management of different post-harvest processes has also been studied, as it can directly affect grain quality and longevity (Albrecht et al. 2009, Barbosa et al. 2014).

Among the operations typically conducted after the soybean harvest, drying and storage deserve a greater attention. Soybean grains need to be dried for reduction of moisture content, in order to ensure a safe and effective storage (Barrozo et al. 2014). However, when drying and storage are carried out without the necessary care, losses may occur in the material quality, such as a decrease in dry matter, and even the depreciation of its visual aspects and certain derivative products, such as crude oil (Jyoti \& Malik 2013, Del Campo et al. 2014, Furquim et al. 2014, Paraginski et al. 2015).

The most commonly questioned procedures adopted during drying and storage are related to the air-drying temperature and storage time and conditions. The air-drying temperature may have an immediate effect on grain quality, and storage conditions may acerbate any resulting damage (Deliberali et al. 2010, Schuh et al. 2011).

Accordingly, the present study aimed at assessing the immediate and latent effect of airdrying temperature on the quality of soybean produced as a second season crop.

\section{MATERIAL AND METHODS}

The study was carried out in two stages. The first consisted of soybean production, which occurred between January and May 2014, at the São Lourenço

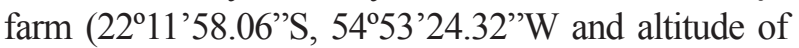
$452 \mathrm{~m}$ ), in Dourados, Mato Gross do Sul State, Brazil. The second stage involved the drying, storage and assessment of grain and crude oil quality, at the Universidade Federal da Grande Dourados, also in Dourados.

The soybean SYN 1059 RR (V-TOP) cultivar was grown under a no-tillage system, using center pivot irrigation. The area preparation included desiccation with Paraquat + Diuron (400 g + $200 \mathrm{~g} \mathrm{ha}^{-1}$ ) and 2,4-Dicholorophenoxy (806 $\mathrm{g} \mathrm{ha}^{-1}$ ), with fertilization applied simultaneously at seeding, using $260 \mathrm{~kg} \mathrm{ha}^{-1}$ of the $02-20-20$ fertilizer formulation (N-P-K), also containing $8 \%$ of $\mathrm{Ca}, 4 \%$ of S, $0.2 \%$ of $\mathrm{Zn}$ and $0.1 \%$ of Bo.
Before planting, the seeds were treated with

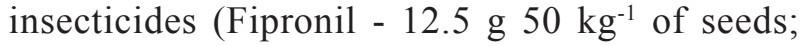

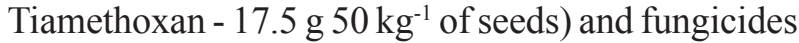
(Metalaxyl-M + Fludioxonil - $0.5 \mathrm{~g}+1.25 \mathrm{~g} 50 \mathrm{~kg}^{-1}$ of seeds). Seeding was mechanically performed, with spacing of $0.45 \mathrm{~m}$ between the sowing lines and density of 18 seeds $\mathrm{m}^{-1}$, obtaining a final population of 355.555 plants ha ${ }^{-1}$.

The grains were manually harvested at their physiological maturity (Fehr \& Caviness 1977), with moisture content of approximately $23 \pm 0.5 \%$ (w.b.). After this stage, they were dried in an experimental fixed-bed dryer, with a drying chamber of $0.80 \mathrm{~m}$ diameter and $1.0 \mathrm{~m}$ height. The experimental dryer uses a series of electric resistors as heating sources, with total power of $12 \mathrm{~kW}$, and an IBRAM fan (model VSI-160) with power of $0.75 \mathrm{~kW}$. Temperature control was achieved using a universal ProportionalIntegral-Derivative (PID) process controller (model $\mathrm{N} 1200$, Novus). The air flow used was $0.2 \mathrm{~m}^{3} \mathrm{~s}^{-1} \mathrm{~m}^{-2}$, selected by a frequency inverter connected to the fan motor.

The experiment was carried out in an $5 \times 5$ splitplot arrangement, with five air-drying temperatures in each plot and five storage periods in each sub-plot, in a completely randomized design. Temperatures of $40{ }^{\circ} \mathrm{C}, 50{ }^{\circ} \mathrm{C}, 60{ }^{\circ} \mathrm{C}, 70{ }^{\circ} \mathrm{C}$ and $80^{\circ} \mathrm{C}$ were used, and around $10 \mathrm{~kg}$ of grains were monitored for each temperature, applying the gravimetric method, until reaching a final moisture content of $12.5 \pm 0.7 \%$ (w.b.). The water reduction rate (WRR) of soy seeds was determined by monitoring the drying process for each selected temperature used. This was determined according to Corrêa et al. (2001), who defined WRR as the amount of water that a certain product loses per dry matter unit per unit of time, as itl follows:

$$
\mathrm{WRR}=\frac{\mathrm{Mw}_{0}-\mathrm{Mw}_{\mathrm{i}}}{\operatorname{DMM}\left(\mathrm{t}_{\mathrm{i}}-\mathrm{t}_{0}\right)}
$$

where WRR = water reduction rate, in $\mathrm{kg} \mathrm{kg}^{-1} \mathrm{~h}^{-1}$; $\mathrm{Mw}_{0}=$ previous total water mass, in $\mathrm{kg} ; \mathrm{Mw}_{\mathrm{i}}=$ current total water mass, in $\mathrm{kg}$; DMM = dry matter mass, in $\mathrm{kg} ; \mathrm{t}_{0}=$ total time for previous drying, in $\mathrm{h} ; \mathrm{t}_{\mathrm{i}}=$ total time for current drying, in h.

After drying, the grains were conditioned through a drying process in non-hermetic metal containers. These, when closed, were kept at environment conditions for a period of 180 days. The quality of soybean, crude oil and moisture content were assessed immediately after drying and every 
45 days subsequently. The temperature and relative humidity of environmental air were recorded during the storage period by using two thermo-hygrometers installed next to the containers.

Dry matter loss, color and crude protein and lipid contents were used to evaluate soybean quality, and the acidity and peroxide indices were used to determine the crude oil quality. Moisture content for each treatment was determined using the gravimetric method, in an oven at $105 \pm 3{ }^{\circ} \mathrm{C}$, for $24 \mathrm{~h}$, with two repetitions (Brasil 2009).

Five repetitions for each treatment were used to assess the dry matter loss of soybean grains during storage. Each repetition was composed of approximately $150 \mathrm{~g}$ of the product, which was placed in perforated waterproof packages. These duly sealed packages were distributed inside the metallic containers together with the remaining soybean mass, with moisture content and wet mass determined immediately and at 45 days after drying. The percentage of dry matter loss was then calculated according to the following equation:

$$
\mathrm{DML}=\frac{\frac{\mathrm{m}_{(\mathrm{i})}}{\left(1+\mathrm{U}_{\mathrm{i}}^{*}\right)}-\frac{\mathrm{m}_{(\theta)}}{\left(1+\mathrm{U}_{\theta}^{*}\right)}}{\frac{\mathrm{m}_{(\mathrm{i})}}{\left(1+\mathrm{U}_{\mathrm{i}}^{*}\right)}} 100
$$

where DML = dry matter loss, \%; $\mathrm{m}_{\text {(i) }}=$ initial sample mass, g.; $\mathrm{m}_{(\theta)}=$ sample mass at time $\theta$, g; $\mathrm{U}_{i}^{*}=$ initial soybean moisture content, decimal d.b.; $\mathrm{U}_{\theta}{ }^{*}=$ soybean moisture content at time $\theta$, decimal d.b.

Color was monitored by direct reading of soybean reflectance in a tristimulus colorimeter (illuminant $\left.10^{\circ} / \mathrm{D} 65\right)$, using the Hunter color scale, determining the values of the coordinates " $L$ " (brightness), "a" (green-red) and "b" (blue-yellow). For each treatment, the average of ten measures was used to determine the color of the product analyzed.

The values of the perceived variations in the "L" $\left[\Delta \mathrm{L}=\mathrm{L}_{(\mathrm{t})}-\mathrm{L}_{(\mathrm{t})}\right]$, "a" $\left[\Delta \mathrm{L}=\mathrm{a}_{(\mathrm{t})}-\mathrm{a}_{(\mathrm{t})}\right]$ and "b" $\left[\Delta \mathrm{L}=\mathrm{b}_{(\mathrm{t})}-\mathrm{b}_{(\mathrm{t})}\right]$ coordinates were used to calculate the color difference $\left(\Delta \mathrm{E}=\sqrt{\Delta \mathrm{L}^{2}+\Delta \mathrm{a}^{2}+\Delta \mathrm{b}^{2}}\right)$ and the chroma index $\left(C_{r}=\sqrt{a^{2}+b^{2}}\right)$, which defines the intensity and purity of a color, where $\Delta \mathrm{E}=$ color difference; $\mathrm{C}_{\mathrm{r}}=$ chroma; $\mathrm{t}=$ storage period, day; $\mathrm{t}_{0}=$ initial period.

The crude protein content was obtained by determining the total nitrogen percentage of three previously ground $100 \mathrm{~g}$ samples, according to the
Kejldahl method, described by the AOAC (1984). The total nitrogen percentage was multiplied by the mean factor of 6.25 , resulting in the crude protein content, expressed in percentage and dry basis (d.b.).

Lipid content was determined according to the AOCS (1993), with the Ac 3-44 method, using three samples of soybean bran weighing $2 \mathrm{~g}$ each. A soxhlet extractor was used for $6 \mathrm{~h}$ and hexane was the solvent. The results were expressed in percentage and d.b.

The acidity index was determined in accordance with the AOCS (2012), using the Ca 5a-40 method, which involved dissolving three $5 \mathrm{~g}$ samples of oil in hot ethyl alcohol $\left(60-65^{\circ} \mathrm{C}\right)$ and titrating with $0.1 \mathrm{~N}$ sodium hydroxide. The volume expended reflected the percentage of free fatty acids, expressed in oleic acid. The equation $\mathrm{AI}=\% \mathrm{FFA} \times \mathrm{F}_{\mathrm{c}}$ was used to convert the percentage of free fatty acids into an acidity index, where $\mathrm{AI}=$ acidity index, in $\mathrm{mg}$ of $\mathrm{KOH} \mathrm{g}^{-1}$ of oil sample; FFA = free fatty acids - oleic acid $(\%) ; \mathrm{F}_{\mathrm{c}}=$ conversion factor -1.99 .

The peroxide index was determined according to the AOCS (2011), using the Cd 8b-90 method, which involved dissolving three $5 \mathrm{~g}$ samples of oil in $50 \mathrm{ml}$ of isooctane acetic acid solution $(3: 2, \mathrm{v} / \mathrm{v})$, with the addition of $0.5 \mathrm{ml}$ of saturated potassium iodine, followed by titration with a solution of $0.1 \mathrm{~N}$ sodium thiosulfate $\left(\mathrm{Na}_{2} \mathrm{~S}_{2} \mathrm{O}_{3}\right)$. The volume used after the addition of $0.5 \mathrm{ml}$ of starch indicator solution showed the peroxide concentration, in meq $\mathrm{kg}^{-1}$, according to the following equation:

$$
\mathrm{PI}=\frac{[\mathrm{N}(\mathrm{A}-\mathrm{B}) 1,000]}{\mathrm{m}}
$$

where $\mathrm{PI}=$ peroxide index, in meq $\mathrm{kg}^{-1}$ of lipid fraction; $\mathrm{A}=$ volume of sodium thiosulfate $\left(\mathrm{Na}_{2} \mathrm{~S}_{2} \mathrm{O}_{3}\right)$ expended with the sample titration, in $\mathrm{ml} ; \mathrm{B}=$ volume of sodium thiosulfate $\left(\mathrm{Na}_{2} \mathrm{~S}_{2} \mathrm{O}_{3}\right)$ expended with titration of reagents without the sample, in $\mathrm{ml}$; $\mathrm{N}=$ normality of the sodium thiosulfate solution $\left(\mathrm{Na}_{2} \mathrm{~S}_{2} \mathrm{O}_{3}\right) ; \mathrm{m}=$ sample mass, in $\mathrm{g}$.

The regression models were fitted using the Statistica 7.0 software. The models were selected taking into consideration the magnitude of the coefficient of determination $\left(\mathrm{R}^{2}\right)$, the significance of the regression, by the F-test, and the phenomenon under study.

\section{RESULTS AND DISCUSSION}

The water reduction rate (WRR) obtained during the soybean drying process was higher with 
an increase in the air-drying temperature, primarily in the first hour of drying (Figure 1). However, over the time, this behavior became more homogeneous in the drying treatments applied, since drying starts to occur under decreasing rates. According to Hall (1980), this drying phase involves more complex water displacement mechanisms from inside to outside the grain, such as liquid diffusion and capillary action, making the process slower.

Thus, the increase in the air temperature helped to promote a faster initial drying, given the more rapid evaporation of particles found in the surface and subsurface. The greater difference in partial vapor pressure between the hotter air and the product favors drying. Moreover, since the initial diffusivity of the water present in the layers just below the subsurface was likely higher, drying was accelerated. A rise in air-drying temperature increases the effective diffusion coefficient of water in the product, raising the drying speed and reducing the time required by the process (Baptestini et al. 2014, Resende et al. 2014, Camicia et al. 2015, Coradi et al. 2016). Costa et al. (2015) report that the diffusion process provides satisfactory estimates of the drying rate of a product, clearly demonstrating the water behavior in the grains, according to the action of the drying temperature imposed.

Figure 2 shows thermal and relative humidity variations during the entire experiment. Therefore, the aforementioned scenario demonstrated that the average temperature during storage was $21.4^{\circ} \mathrm{C}$, with a maximum and minimum of $28.4^{\circ} \mathrm{C}$ and $14.5^{\circ} \mathrm{C}$, respectively. With respect to relative humidity, the average value observed was $57.9 \%$, with a recorded maximum of $83.4 \%$ and minimum of $47.3 \%$.

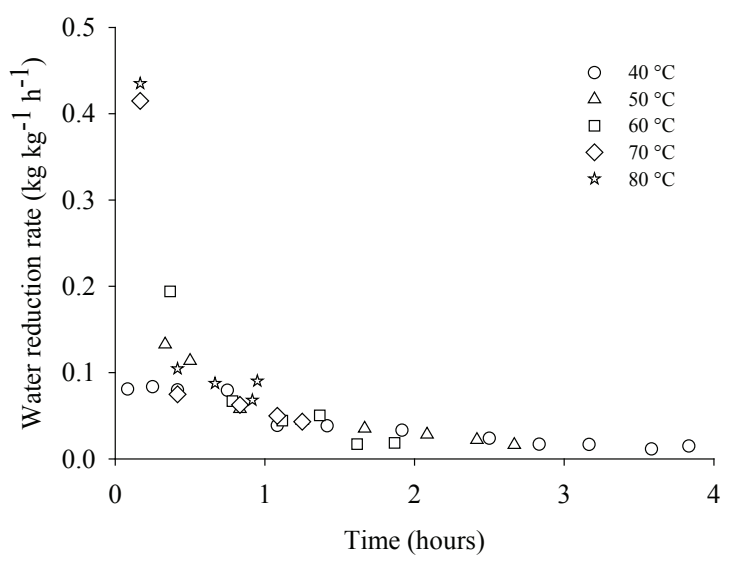

Figure 1. Water reduction rate for soybean, during the drying process, at different temperatures.
Table 1 shows the oscillations in the water content of grains during storage, due to its hygroscopicity, and because of the non-controlled temperature and relative humidity that induce the sorption and desorption phenomena (Tiecker Junior et al. 2014, Bessa et al. 2015). During the 180 days of storage, it was also found that all the treatments exhibited increases in moisture content at 45 and 180 days, possibly because these two assessment points followed periods of higher relative humidity, thereby favoring sorption processes.

Nevertheless, generally, a decrease in moisture content was observed in all the treatments (Table 1), likely due to the decline in the relative humidity over time (Figure 2) and the chemical composition of the grains. Soybean tends to retain less water internally, because of its oily substances, which are hydrophobic (Dios 1984).

It was observed that as air-drying temperature rose, the loss of dry matter during storage also increased. This loss worsened with the storage time (Figure 3).

At 45 days of storage, it was observed that the dry matter loss occurred only for grains dried at

Table 1. Average moisture content values (\% w.b.) of soybean, as a function of air-drying temperature and storage time.

\begin{tabular}{cccccc}
\hline \multirow{2}{*}{$\begin{array}{c}\text { Storage time } \\
\text { (days) }\end{array}$} & \multicolumn{5}{c}{ Drying temperature $\left({ }^{\circ} \mathrm{C}\right)$} \\
\cline { 2 - 6 } & 40 & 50 & 60 & 70 & 80 \\
\hline 0 & 13.2 & 12.7 & 12.4 & 12.5 & 12.0 \\
45 & 13.4 & 12.8 & 12.4 & 12.6 & 12.3 \\
90 & 12.6 & 12.1 & 12.0 & 11.8 & 11.4 \\
135 & 11.1 & 10.6 & 10.6 & 10.5 & 10.2 \\
180 & 11.3 & 11.0 & 10.8 & 10.8 & 10.4 \\
\hline
\end{tabular}

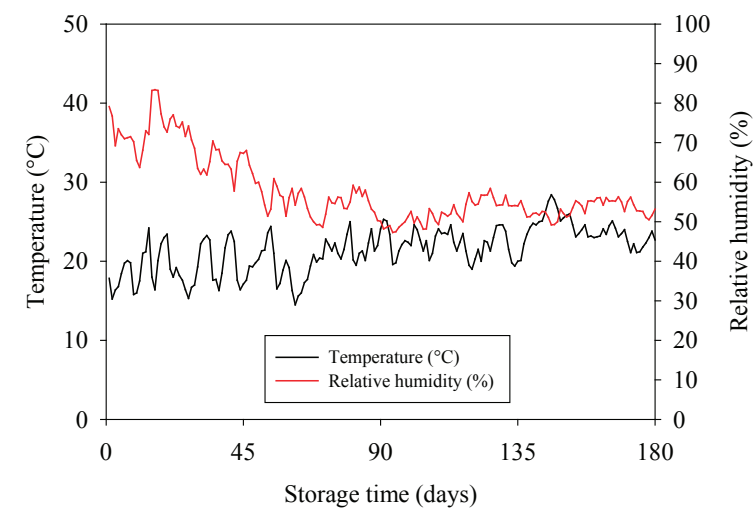

Figure 2. Average daily temperature and relative humidity during 180 days of soybean storage under a non-controlled environment. 
temperatures of $60{ }^{\circ} \mathrm{C}, 70{ }^{\circ} \mathrm{C}$ and $80{ }^{\circ} \mathrm{C}$. However, at 90 days of storage, the increase in the air-drying temperature caused a rise in the dry matter loss in the soybean, which was higher over time (Figure 3).

After 180 days of storage, the soybean grains dried at $40{ }^{\circ} \mathrm{C}, 50{ }^{\circ} \mathrm{C}, 60{ }^{\circ} \mathrm{C}, 70{ }^{\circ} \mathrm{C}$ and $80{ }^{\circ} \mathrm{C}$ exhibited dry matter losses of $0.81 \%, 0.87 \%, 0.99 \%$, $1.17 \%$ and $1.41 \%$, respectively, confirming that the temperature of the batches is a decisive factor in preserving their quality. The increase in the drying temperature caused a rise in WRR, possibly resulting in damage to the tegumentary and cotyledonary tissues of the grains, as reported by Darvishi et al. (2015). Thus, the interaction between the material and the storage environment was likely facilitated. This may have aggravated the dry matter loss during storage, which, according to Del Campo et al. (2014), is directly responsive to temperature and humidity conditions, given the ability of both to interfere in the respiratory process of the material and dry matter consumption.

Nevertheless, since average temperature and relative humidity during the experiment were theoretically low (Figure 2), the maintenance of the material was efficient. This is evident by the low dry matter losses during storage, even in the treatment submitted to $80^{\circ} \mathrm{C}$. Dry loss is generally intensified under hotter and more humid conditions, reducing parameters directly related, such as apparent specific gravity, as reported by Alencar et al. (2009) in soybean. Taking the final dry matter loss after 180 days

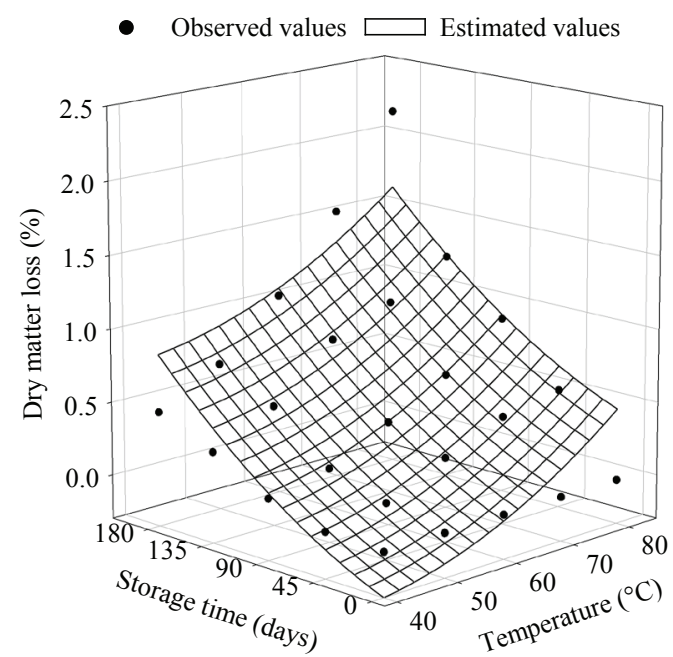

$\mathrm{DML}=-0.0211 \mathrm{ADT}+0.0036 \mathrm{ST}+0.0003 \mathrm{ADT}^{2}+1,6403 \times 10^{-5} \mathrm{ST}^{2} \quad\left(\mathrm{R}^{2}=0.8348\right)$

Figure 3. Loss of soybean dry matter, as a function of air-drying temperature and storage time. of storage and dividing the result by 6 , in accordance with the number of storage months, showed that the dry matter loss did not exceed $0.30 \%$ in any of the conditions studied, which is the practical index adopted by a number of storage companies in Brazil.

Like observed for dry matter, the color of soybean grains during storage changed. However, this behavior is indifferent to the drying temperature used (Figure 4a).

The change in color occurred due to the darkening of grains, evidenced by the decreasing of "L" and "b" coordinate values (Figures 4b and $4 \mathrm{~d}$ ), and increasing of "a" coordinate values (Figure 4c). These results reflect darker shades, such as black instead of white (Figure 4b), and blue instead of yellow (Figure 4d). There was an increase in the metabolic rate with storage time, as shown by the loss of dry matter (Figure 3 ), resulting in a darkening of the grains. Color variables were, therefore, directly related to loss of quality (Lima et al. 2014). Furthermore, the fact that the initial color of the grains was altered as a result of tegumentary darkening can also be confirmed by the chroma index, given that this parameter reveals the extent to which the saturation of the characteristic grain colors is reduced, resulting in more greyish shades, as proposed by McGuire (1992) (Figure 5).

Both temperature and relative humidity of the storage environment changed during the experiment, primarily in the first 45 days, when the relative humidity reached values greater than $60 \%$ (Table 1). This change influenced results, since storage environment and time can affect the quality and appearance of the stored material (Smaniotto et al. 2014).

In the assessments of crude protein and lipid content, immediate and latent reductions were also observed for both variables, correlating with the increase in the factors studied (drying temperature and storage time) (Figure 6).

The crude protein content after drying at temperatures of $40{ }^{\circ} \mathrm{C}, 50{ }^{\circ} \mathrm{C}, 60{ }^{\circ} \mathrm{C}, 70{ }^{\circ} \mathrm{C}$ and $80{ }^{\circ} \mathrm{C}$ was $39.06 \%, 38.94 \%, 38.82 \%, 38.69 \%$ and $38.57 \%$, respectively (Figure 6a). However, grain deterioration during storage caused a reduction of only approximately $0.8 \%$ in proteins, for all treatments, after 180 days. Thus, the final values observed for the variable, at the same drying temperatures tested, were $38.76 \%, 38.63 \%, 38.51 \%, 38.39 \%$ and $38.26 \%$.

The lipid content obtained after drying at temperatures of $40^{\circ} \mathrm{C}, 50{ }^{\circ} \mathrm{C}, 60^{\circ} \mathrm{C}, 70{ }^{\circ} \mathrm{C}$ and $80^{\circ} \mathrm{C}$ 
- Observed values

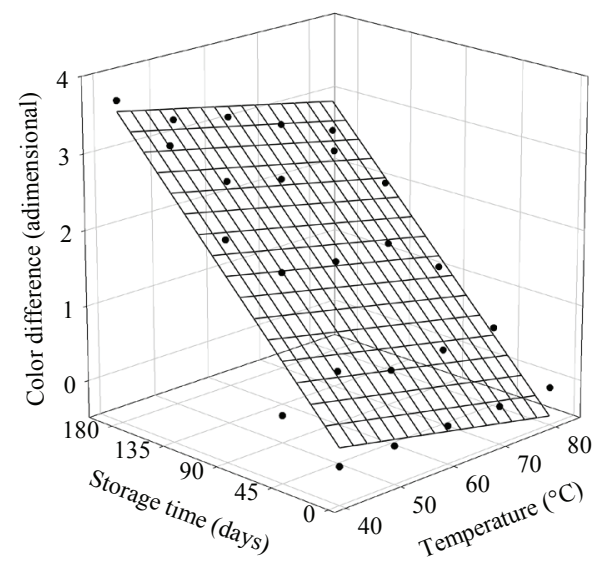

(a)

$\Delta \mathrm{E}=0.8601-0.0155 \mathrm{ADT}+0.0187 \mathrm{ST} \quad\left(\mathrm{R}^{2}=0.9417\right)$

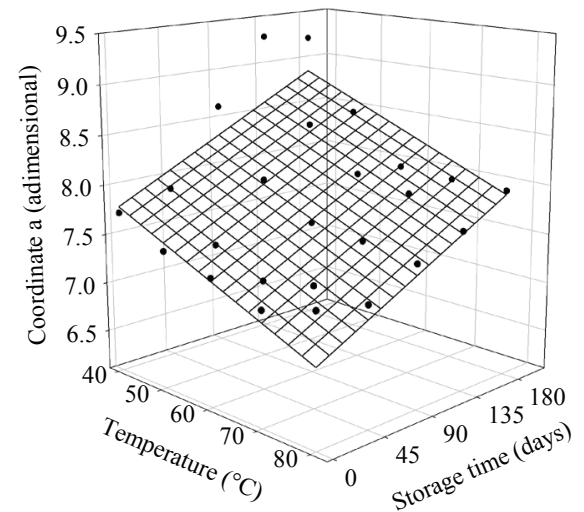

(c)

$\mathrm{a}=8.7130-0.0230 \mathrm{ADT}+0.0059 \mathrm{ST} \quad\left(\mathrm{R}^{2}=0.7625\right)$

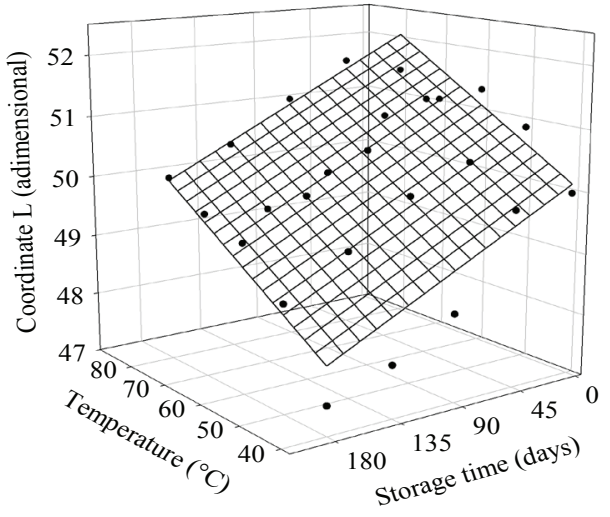

(b)

$\mathrm{L}=48.1740+0.0486 \mathrm{ADT}-0.0114 \mathrm{ST} \quad\left(\mathrm{R}^{2}=0.8368\right)$

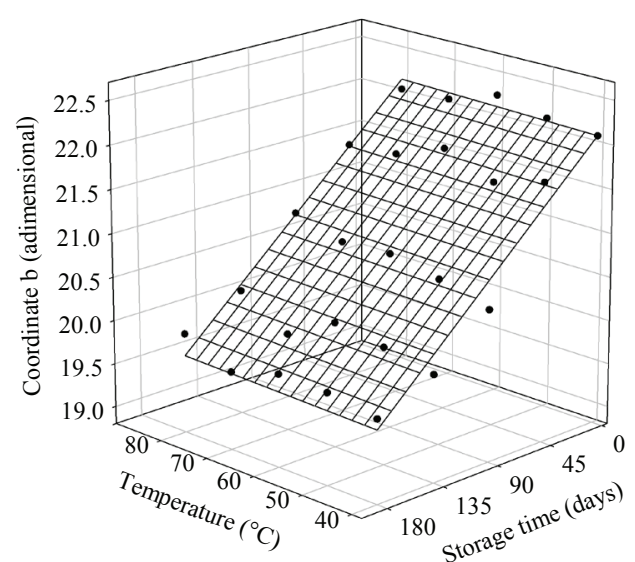

(d)

$\mathrm{b}=22.0358+0.0015 \mathrm{ADT}-0.0137 \mathrm{ST} \quad\left(\mathrm{R}^{2}=0.9572\right)$

Figure 4. Results for color difference (a) and color coordinates "L" (b), "a" (c) and "b" (d) of soybean, as a function of air-drying temperature and storage time.

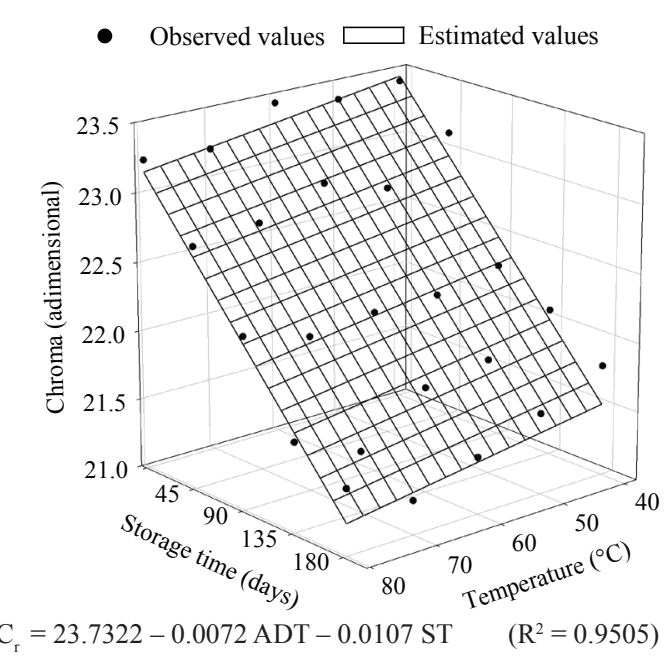

Figure 5. Results for the soybean chroma index, as a function of air-drying temperature and storage time. was $19.46 \%, 19.35 \%, 19.25 \%, 19.14 \%$ and $19.03 \%$, respectively (Figure 6b). After 180 days, the lipid content decline of approximately $2.71 \%$ for the treatments, so the values obtained after 180 days of storage, were $18.94 \%, 18.83 \%, 18.72 \%, 18.62 \%$ and $18.51 \%$.

Thus, it can be hypothesized that reducing both variables by increasing the factors applied contributed to the increasing dry matter loss (Figure 3), given that proteins and lipids are the two main constituents of soybean. According to Delarmelino-Ferraresi et al. (2014), the chemical composition of soybean directly reflects its condition, indicating relationships between constituent and qualitative-quantitative variables. Furthermore, according to Surki et al. (2012), both drying temperature and storage period for soybean may have a negative effect on the composition of the 
product, destabilizing its metabolism, in addition to its reserves.

Taking into account that both the immediate and latent harmful effects were more intense for the lipid fraction, the action of degrading and deteriorative processes was probably more critical in lipids, due to the low chemical stability of this component. Thus, lipid content is commonly considered an indication of early grain deterioration, given that the hydrolysis of the fatty material starts more quickly than that of proteins or carbohydrates. This was also reported by Marini et al. (2005), who assessed the stability of oat.
With respect to the quality of crude oil extracted from soybean, it was found that as the airdrying temperature rose, the acidity and peroxide indices increased only slightly, despite the evidence of a decline in the quality of the subproduct obtained. However, the latent effect observed suggests that increases in both variables occurred due to the immediate damage caused by the rise in temperature. The deteriorative processes were more significant in crude oil from grains dried at higher temperatures, and therefore better differentiated the drying treatments applied (Figure 7).

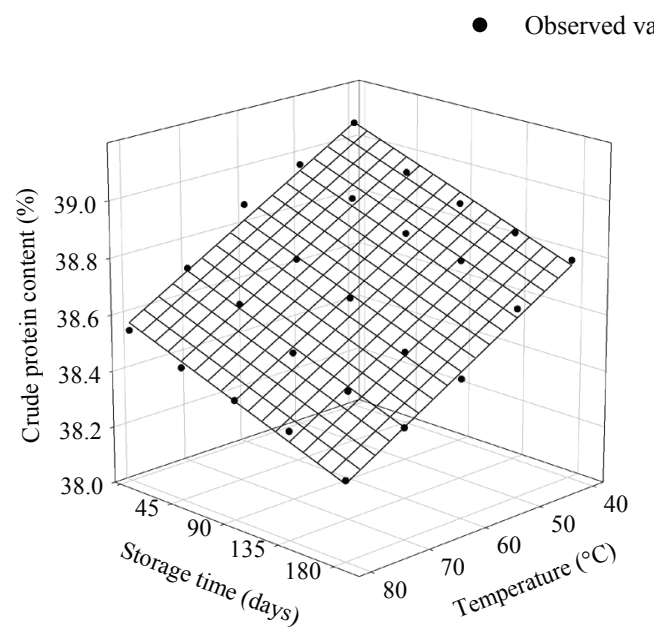

(a)

$\mathrm{CPC}=39.5548-0.0123 \mathrm{ADT}-0.0017 \mathrm{ST} \quad\left(\mathrm{R}^{2}=0.9735\right)$ $\square$ Estimated values

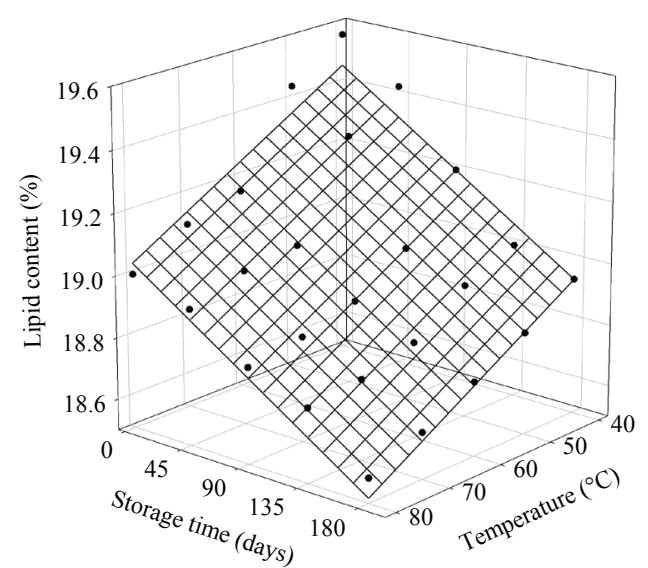

(b)

$\mathrm{LC}=19.8816-0.0106 \mathrm{ADT}-0.0029 \mathrm{ST} \quad\left(\mathrm{R}^{2}=0.9248\right)$

Figure 6. Results for crude protein (a) and lipid content (b) of soybean, as a function of air-drying temperature and storage time.

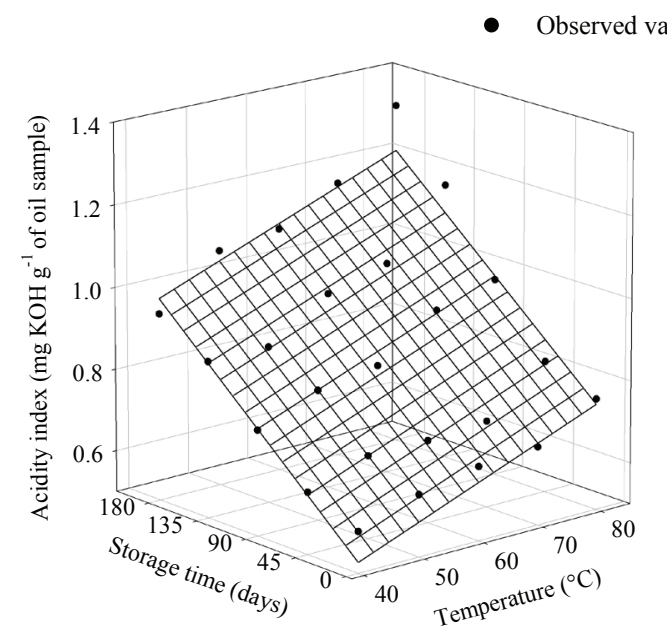

(a)

$$
\mathrm{AI}=0.2956+0.0058 \mathrm{ADT}+0.0026 \mathrm{ST} \quad\left(\mathrm{R}^{2}=0.9349\right)
$$

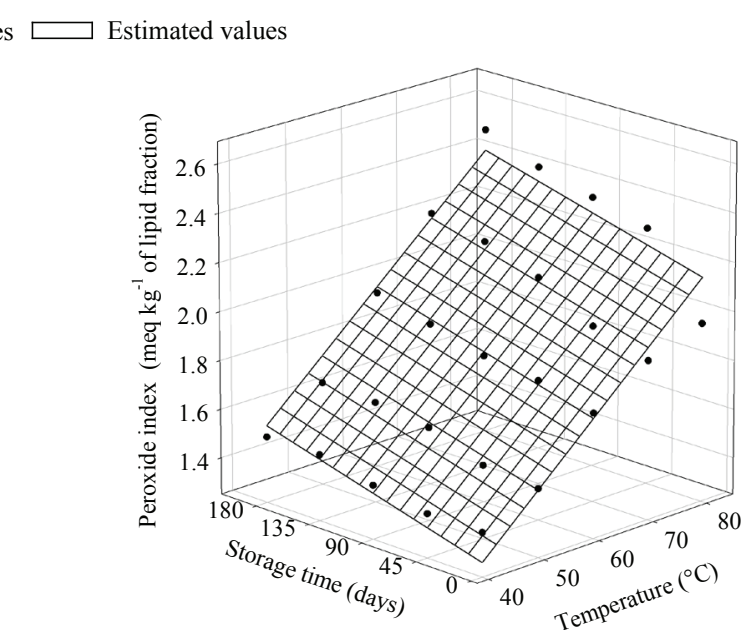

(b)

Figure 7. Results for acidity (a) and peroxide indices (b) of crude oil extracted from soybean, as a function of air-drying temperature and storage time. 
The acidity index values for crude oil extracted from grains dried at $40{ }^{\circ} \mathrm{C}, 50{ }^{\circ} \mathrm{C}, 60{ }^{\circ} \mathrm{C}, 70{ }^{\circ} \mathrm{C}$ and $80{ }^{\circ} \mathrm{C}$ were $0.53 \mathrm{mg}$ of $\mathrm{KOH} \mathrm{g} \mathrm{g}^{-1}, 0.59 \mathrm{mg}$ of $\mathrm{KOH} \mathrm{g}{ }^{-1}, 0.64 \mathrm{mg}$ of $\mathrm{KOH} \mathrm{g}{ }^{-1}, 0.70 \mathrm{mg}$ of $\mathrm{KOH} \mathrm{g}{ }^{-1}$ and $0.76 \mathrm{mg}$ of $\mathrm{KOH} \mathrm{g}{ }^{-1}$ of sample. However, at the end of the experiment, the values for this variable, at the same drying temperatures, were $1.00 \mathrm{mg}$ of $\mathrm{KOH} \mathrm{g}{ }^{-1}, 1.05 \mathrm{mg}$ of $\mathrm{KOH} \mathrm{g}{ }^{-1}, 1.11 \mathrm{mg}^{\circ} \mathrm{KOH} \mathrm{g}^{-1}$, $1.17 \mathrm{mg}$ of $\mathrm{KOH} \mathrm{g}^{-1}$ and $1.23 \mathrm{mg}$ of $\mathrm{KOH} \mathrm{g}^{-1}$ of sample (Figure 7a). The immediate peroxide index values were 1.31 meq kg-1, 1.52 meq $\mathrm{kg}^{-1}, 1.74$ meq kg-1 , $1.95 \mathrm{meq} \mathrm{kg}^{-1}$ and $2.17 \mathrm{meq} \mathrm{kg}^{-1}$ of the lipid fraction, and 1.56 meq kg-1, 1.78 meq $\mathrm{kg}^{-1}, 1.99$ meq $\mathrm{kg}^{-1}$, $2.21 \mathrm{meq} \mathrm{kg}^{-1}$ and $2.42 \mathrm{meq}^{-1}$ of the lipid fraction at the end of the experiment (Figure $7 \mathrm{~b}$ ).

Despite the depreciation of the crude oil, due to the action of both temperature and storage time imposed to the grains, at the end of the experiment, the values of the two descriptive variables were lower than the limits established by Anvisa (Brasil 2005). This regulatory agency forbids the sale of crude soybean oil in Brazil with acidity indices above $4.0 \mathrm{mg}$ of $\mathrm{KOH} \mathrm{g}^{-1}$ of sample and peroxide indices greater than 15.0 meq $\mathrm{kg}^{-1}$ of the lipid fraction.

\section{CONCLUSIONS}

1. The increase in the air-drying temperature and storage time have negative influence on the quality of soybean and its subproducts;

2. Drying at $40{ }^{\circ} \mathrm{C}$ has the least effect on the quality of soybean, as well as crude oil, when compared to the higher temperatures evaluated.

\section{ACKNOWLEDGMENTS}

The authors would like to thank the Coordenação de Aperfeiçoamento de Pessoal de Nível Superior (Capes) and the Fundação de Apoio ao Desenvolvimento do Ensino, Ciência e Tecnologia do Estado de Mato Grosso do Sul (Fundect).

\section{REFERENCES}

ALBRECHT, L. P. et al. Sementes de soja produzidas em épocas de safrinha na região oeste do Estado do Paraná. Acta Scientiarum Agronomy, v. 31, n. 1, p. 121-127, 2009.

ALENCAR, E. R. et al. Qualidade dos grãos de soja armazenados em diferentes condições. Revista Brasileira de Engenharia Agrícola e Ambiental, v. 13, n. 5, p. 606613, 2009.

AMERICAN OIL CHEMISTS SOCIETY (AOCS). Official methods and recommended practices of the American Oil Chemists Society [AOCS Official method Ac 3-44]. 4th ed. Champaign: AOCS, 1993.

AMERICAN OIL CHEMISTS SOCIETY (AOCS). Official methods and recommended practices of the American Oil Chemists Society [AOCS Official method Cd 8b-90]. 6th ed. Champaign: AOCS, 2011.

AMERICAN OIL CHEMISTS SOCIETY (AOCS). Official methods and recommended practices of the American Oil Chemists Society [AOCS Official method Ca 5a-40]. 6th ed. Champaign: AOCS, 2012.

ASSOCIATION OF OFFICIAL ANALYTICAL CHEMISTS (AOAC). Official methods of analysis of the Association of Official Analytical Chemists. Washington, DC: AOAC, 1984.

BAPTESTINI, F. M. et al. The effect of harvest conditions and drying temperature on drying kinetics of two popcorn genotypes. African Journal of Agricultural Research, v. 9, n. 39, p. 2964-2970, 2014.

BARBOSA, R. M. et al. Qualidade fisiológica e sanitária de sementes de amendoim durante o processo de produção. Pesquisa Agropecuária Brasileira, v. 49, n. 12, p. 977985, 2014.

BARROZO, M. A. S.; MUJUMDAR, A.; FREIRE, J. T. Air-drying of seeds: a review. Drying Technology, v. 32, n. 10, p. 1127-1141, 2014.

BESSA, J. F. V. et al. Armazenamento do crambe em diferentes embalagens e ambientes: parte I - qualidade fisiológica. Revista Brasileira de Engenharia Agrícola e Ambiental, v. 19, n. 3, p. 224-230, 2015.

BEZERRA, A. R. G. et al. Importância econômica. In: SEDIYAMA, T.; SILVA, F.; BORÉM, A. (Eds.). Soja: do plantio à colheita. Viçosa: Ed. UFV, 2015. p. 9-26.

BRASIL. Ministério da Agricultura, Pecuária e Abastecimento. Regras para análise de sementes. Brasília, DF: MAPA/ACS, 2009.

BRASIL. Ministério da Saúde. Agência Nacional de Vigilância Sanitária (Anvisa). Regulamento técnico para óleos vegetais, gorduras vegetais e creme vegetal. Resolução RDC n. 270 de 22/09/2005. Diário Oficial da República Federativa do Brasil, Brasília, DF, 23 set. 2005. Seção 1, p. 184.

CAMICIA, R. G. M. et al. Modelagem do processo de secagem de sementes de feijão-caupi. Revista Caatinga, v. 28 , n. 3, p. 206-214, 2015. 
COMPANHIA NACIONAL DE ABASTECIMENTO (Conab). Acompanhamento da safra brasileira de grãos: monitoramento agrícola safra 2015/2015. 2016. Available at: <http://www.conab.gov.br/OlalaCMS/ uploads/arquivos/16_07_29_15_12_51_boletim_graos julho_2016.pdf>. Access on: 02 Aug. 2016.

CORADI, P. C.; FERNANDES, C. H. P.; HELMICH, J. C. Adjustment of mathematical models and quality of soybean grains in the drying with high temperatures. Revista Brasileira de Engenharia Agrícola e Ambiental, v. 20, n. 4, p. 385-392, 2016.

CORRÊA, P. C.; MACHADO, P. F.; ANDRADE, E. T. Cinética de secagem e qualidade de grãos de milho-pipoca. Ciência e Agrotecnologia, v. 25, n. 1, p. 134-142, 2001.

COSTA, L. M. et al. Modelagem matemática da secagem de frutos de crambe em camada delgada. Bioscience Journal, v. 31, n. 2, p. 392-403, 2015.

DARVISHI, H.; KHOSHTAGHAZA, M. H.; MINAEI, S. Effects of fluidized bed drying on the quality of soybean kernels. Journal of the Saudi Society of Agricultural Sciences, v. 14, n. 2, p. 134-139, 2015.

DEL CAMPO, B. G. et al. Corn cob dry matter loss in storage as affected by temperature and moisture content. Transactions of the American Society of Agricultural and Biological Engineers, v. 52, n. 2, p. 573-578, 2014.

DELARMELINO-FERRARESI, L. M.; VILLELA, F. A.; AUMONDE, T. Z. Desempenho fisiológico e composição química de sementes de soja. Revista Brasileira de Ciências Agrárias, v. 9, n. 1, p. 14-18, 2014.

DELIBERALI, J. et al. Efeitos de processo de secagem e tempo de armazenamento na qualidade tecnológica de trigo. Ciência e Agrotecnologia, v. 34, n. 5, p. 1285-1292, 2010.

DIOS, C. A. D. Recomendaciones sobre el manejo y poscosecha del girasol. Pergamino: Estación Experimental Agropecuária de Pergamino, 1984.

FEHR, W. R.; CAVINESS, C. E. Stages of soybean development. Ames: Iowa State University of Science and Technology, 1977.

FURQUIM, L. C. et al. Efeito da secagem e do armazenamento das sementes de pinhão-manso (Jatropha curcas L.) na qualidade do óleo. Revista Cientifica, v. 1, n. 1, p. 51-70, 2014.

HALL, C. W. Drying and storage of agricultural crops. Westport: AVI Publishing Company, 1980.
JYOTI, U.; MALIK, C. P. Seed deterioration: a review. International Journal of Life Sciences Biotechnology \& Pharma Research, v. 2, n. 3, p. 373-386, 2013.

LIMA, R. A. Z.; TOMÉ, L. M.; ABREU, C. M. P. Embalagem a vácuo: efeito no escurecimento e endurecimento do feijão durante o armazenamento. Ciência Rural, v. 44, n. 9, p. 1664-1670, 2014.

MARINI, L. J. et al. Efeito da secagem intermitente na estabilidade de grãos de aveia branca. Brazilian Journal of Food Technology, v. 8, n. 3, p. 260-267, 2005.

MCGUIRE, R. G. Reporting of objective color measurements. Hortscience, v. 27, n. 12, p. 1254-1255, 1992.

PARAGINSKI, R. T. et al. Qualidade de grãos de milho armazenados em diferentes temperaturas. Revista Brasileira de Engenharia Agricola e Ambiental, v. 19, n. 4, p. 358-363, 2015.

RESENDE, O. et al. Knetics and thermodynamic properties of drying process of sorghum (Sorghum bicolor [L.] Moench) grains. African Journal of Agricultural Research, v. 9, n. 32, p. 2453-2462, 2014.

SCHUH, G. et al. Efeitos de dois métodos de secagem sobre a qualidade físico-química de grãos de milho safrinha - RS, armazenados por 6 meses. Semina: Ciências Agrárias, v. 32, n. 1, p. 235-244, 2011.

SEDIYAMA, T.; OLIVEIRA, R. C. T.; NOGUEIRA, A. P. O. Importância econômica da semente. In: SEDIYAMA, T. (Ed.). Tecnologia de produção de sementes de soja. Londrina: Mecenas, 2013. p. 11-14.

SMANIOTTO, T. A. S. et al. Qualidade fisiológica das sementes de soja armazenadas em diferentes condições. Revista Brasileira de Engenharia Agrícola e Ambiental, v. 18, n. 4, p. 446-453, 2014.

SURKI, A. A.; SHARIFZADEH, F.; AFSHARI, R. T. Effect of drying conditions and harvest time on soybean seed viability and deterioration under different storage temperatures. African Journal of Agricultural Research, v. 7, n. 36, p. 5118-5127, 2012.

TIECKER JUNIOR, A. et al. Qualidade físico-química de grãos de milho armazenados com diferentes umidades em ambientes hermético e não hermético. Revista Brasileira de Milho e Sorgo, v. 13, n. 2, p. 174-186, 2014. 